\title{
Effect of NAA and Ethrel on Flowering Characteristics of Pineapple (Ananas comosus L. Merr.) Var. Queen
}

\author{
Usha Kumari $^{1 *}$, K. K. Jha ${ }^{1}$, S. Sengupta ${ }^{1}$, S. Misra ${ }^{1}$, A. K. Tiwary ${ }^{1}$ and M. Chakraborty ${ }^{2}$ \\ ${ }^{1}$ Department of Horticulture, ${ }^{2}$ Department of Genetics and Plant Breeding, \\ Birsa Agricultural University, Kanke, Ranchi, India \\ *Corresponding author
}

\begin{abstract}
A B S T R A C T
The present experiment entitled "Effect of NAA and Ethrel on flowering characteristics of pineapple (Ananas comosus L. Merr.) Var. Queen" was conducted at the Agri-technology

Park, Birsa Agricultural University, Kanke, Ranchiduring 2017-2020. The experiment was laid out in Factorial Randomized Block Designed having two factors the Factor A consisted twelve growth regulators and their combination viz. NAA $10 \mathrm{ppm}\left(\mathrm{G}_{1}\right)$, NAA 20ppm $\left(\mathrm{G}_{2}\right)$, Ethrel 10ppm $\left(\mathrm{G}_{3}\right)$, Ethrel 30ppm $\left(\mathrm{G}_{4}\right)$, Ethrel 50ppm $\left(\mathrm{G}_{5}\right)$, NAA 10ppm + Ethrel 10ppm $\left(\mathrm{G}_{6}\right)$, NAA 10ppm + Ethrel 30ppm $\left(\mathrm{G}_{7}\right)$, NAA 10ppm + Ethrel 50ppm $\left(\mathrm{G}_{8}\right)$, NAA 20ppm + Ethrel 10ppm $\left(\mathrm{G}_{9}\right)$, NAA 20ppm + Ethrel 30ppm $\left(\mathrm{G}_{10}\right)$, NAA 20ppm + Ethrel 50ppm $\left(\mathrm{G}_{11}\right)$ and Control $\left(\mathrm{G}_{12}\right)$ and Factor B consisted three stages of spray i.e. 30 leaves stage $\left(S_{1}\right)$, 35 leaves stage $\left(S_{2}\right)$ and 40 leaves stage $\left(S_{3}\right)$.With respect to growth regulators, significantly maximum Flowering percent and minimum days to flowering were recorded with Ethrel $30 \mathrm{ppm}$. In case of stage of spray, it was found statistically most effective and maximum flowering percent and minimum days taken for flowering after spray were registered with 40 leaves stage. Interaction effect of growth regulators and stage of spray show a significant influence with respect to flowering attributes studied in present investigation.
\end{abstract}

Keywords

Pineapple,

Flowering

characteristics

Article Info

Accepted:

20 October 2020

Available Online:

10 November 2020

\section{Introduction}

Pineapple has always been an important economic crop due to its fruit characteristics. Statistics on world pineapple production are collected by the Food and Agriculture Organization of the United Nations (FAO). According to FAO statistics (2018), the leading pineapple-producing countries are Costa Rica, Philippines, Brazil, Thailand, Indonesia and India. The fruit is consumed fresh by many people and hence, source of essential mineral elements, nutrients and vitamins. It could easily be processed into jams, alcoholic and nonalcoholic drinks and other confectionaries. It is an important source of income to pineapple growers. Natural flowering is an obstacle for the management of pineapple production. This phenomenon is at the origin of considerable and increasing fruit losses on an international scale (Cunha et al., 2003). Increase in pineapple production involves flower induction, which is necessary for uniform 
fruiting and maturity. This study is therefore aimed at assessing the suitable concentration of NAA and Ethrel for its effect on flowering attributes of pineapple.

The present experiment was carried out at the Agri-technology Park, Birsa Agricultural University, Kanke, Ranchi during 2017-2020 with a commercial pineapple var. Queen. The selected plants were uniform in size and with $30 \mathrm{~cm} \times 60 \mathrm{~cm} \times 90 \mathrm{~cm}$ spacing. The growth regulators NAA 10ppm $\left(\mathrm{G}_{1}\right)$, NAA 20ppm $\left(\mathrm{G}_{2}\right)$, Ethrel 10ppm $\left(\mathrm{G}_{3}\right)$, Ethrel 30ppm $\left(\mathrm{G}_{4}\right)$, Ethrel 50ppm $\left(\mathrm{G}_{5}\right)$, NAA $10 \mathrm{ppm}+$ Ethrel $10 \mathrm{ppm}\left(\mathrm{G}_{6}\right)$, NAA $10 \mathrm{ppm}+$ Ethrel 30ppm $\left(\mathrm{G}_{7}\right)$, NAA 10ppm + Ethrel 50ppm $\left(\mathrm{G}_{8}\right)$, NAA $20 \mathrm{ppm}+$ Ethrel 10ppm $\left(\mathrm{G}_{9}\right)$, NAA 20ppm + Ethrel 30ppm $\left(\mathrm{G}_{10}\right)$, NAA 20ppm + Ethrel 50ppm $\left(\mathrm{G}_{11}\right)$ along with waterspray/control $\left(G_{12}\right)$ were applied as foliar spray.at 30.35 and 40 leaves stage. Recommended package of practices including application ofN:P: $\mathrm{K}$ of 12:6:12 g/ plant/ year, plant protection, weed control were followed. The experiment was carried out in Factorial Randomized Block design with three replications.

\section{Results and Discussion}

\section{Flowering (\%)}

The data pertaining to the effect of growth regulators, stage of spray and their interaction on flowering percent are presented in Table 1.

Irrespective of stages, flowering percent differed markedly among growth regulators. It was significantly maximum $(87.31 \%)$ at Ethrel $30 \mathrm{ppm}\left(\mathrm{G}_{4}\right)$. Which was at par with Ethrel $10 \mathrm{ppm}(85.50 \%)$, NAA $10 \mathrm{ppm}+$ Ethrel 10 ppm (84.88\%) NAA 20 ppm + Ethrel $10 \mathrm{ppm}$ (83.07\%), Ethrel $50 \mathrm{ppm}$ $(82.86 \%)$ and NAA 10 ppm (82.55 $\%)$.Whereas it was minimum $(48.77 \%)$ in control $\left(\mathrm{G}_{12}\right)$.
Flowering percent differed significantly due to stage of spray over growth regulators. It was significantly more $(85.27 \%)$ in 40 leaves stage $\left(S_{3}\right)$ than 30 leaves stage $(74.76 \%)$.

The interaction between growth regulators and stage of spray on flowering percent was found to be significant. Maximum flowering percent $(94.32 \%)$ was observed with Ethrel $30 \mathrm{ppm}$ and 40 leaves stage. Which was closely followed by Ethrel $50 \mathrm{ppm}$ and 40 leaves stage $(92.51 \%)$, Ethrel $10 \mathrm{ppm}$ and 40 leaves stage $(92.23 \%)$, NAA $10 \mathrm{ppm}+$ Ethrel $10 \mathrm{ppm}$ and 40 leaves stage (90.74\%), NAA $10 \mathrm{ppm}+$ Ethrel $10 \mathrm{ppm}$ and 35 leaves stage (90.54\%), NAA 10 ppm and 40 leaves stage $(90.23 \%)$, NAA $10 \mathrm{ppm}+$ Ethrel $30 \mathrm{ppm}$ and 40 leaves stage $(90.21 \%)$, NAA $20 \mathrm{ppm}$ and 40 leaves stage $(89.64 \%)$, NAA 20 ppm + Ethrel 10 ppm and 40 leaves stage $(87.02 \%)$, Ethrel $10 \mathrm{ppm}$ and 35 leaves stage (87.02\%),NAA $10 \mathrm{ppm}+$ Ethrel $50 \mathrm{ppm}$ and 40 leaves stage $(85.82 \%)$, Ethrel $30 \mathrm{ppm}$ and 35 leaves stage $(85.54 \%)$.

\section{Flowering (Days)}

A glance of the results from the Table 2 revealed that, growth regulators and different stages of spray to pineapple fruit had a positive influence on number of days taken for initiation of flowering.

Early flowering (34.44 days) was noticed in plants grown under treatment Ethrel $30 \mathrm{ppm}$ $\left(\mathrm{G}_{4}\right)$, which was closely followed by treatment Ethrel 10 ppm (35.06days), Ethrel 50 ppm (35.17 days), NAA 20 ppm (35.61 days), NAA 10 ppm (36.22 days), NAA 10 ppm + Ethrel 30 ppm (36.33 days), NAA 10 ppm + Ethrel 10 ppm (36.44 days), NAA 10 ppm + Ethrel 50 ppm (37.00days) and NAA $20 \mathrm{ppm}+$ Ethrel $10 \operatorname{ppm}(38.33$ days $)$. Delayed flowering (65.11 days) was recorded in $\left(\mathrm{G}_{12}\right)$ control. 
Table.1 Flowering (\%) of pineapple as influenced by various treatments

\begin{tabular}{|c|c|c|c|c|c|c|c|c|c|c|c|c|c|}
\hline \multicolumn{2}{|r|}{ Growth regulators } & & \multirow{3}{*}{\multicolumn{2}{|c|}{$\begin{array}{c}\text { 2017- } 2019 \\
\text { Stage of spray }(\mathrm{S})\end{array}$}} & \multirow{5}{*}{$\begin{array}{l}\text { Mea } \\
\text { n }\end{array}$} & \multirow{5}{*}{$\begin{array}{c}\mathrm{S}_{1} \\
(30 \\
\mathbf{L S})\end{array}$} & \multirow{3}{*}{\multicolumn{2}{|c|}{$\begin{array}{c}\text { 2018-2020 } \\
\text { Stage of spray }(\mathrm{S})\end{array}$}} & \multirow{5}{*}{ Mean } & \multirow{5}{*}{$\begin{array}{l}\mathrm{S}_{1} \\
\mathbf{3 0} \\
\mathrm{LS})\end{array}$} & \multirow{3}{*}{\multicolumn{2}{|c|}{\begin{tabular}{l}
\multicolumn{1}{c}{ Pooled } \\
Stage of spray \\
(S)
\end{tabular}}} & \multirow{5}{*}{$\begin{array}{l}\text { Mea } \\
\text { n }\end{array}$} \\
\hline & & & & & & & & & & & & & \\
\hline & & \multirow{3}{*}{$\begin{array}{c}\mathrm{S}_{1} \\
\mathbf{( 3 0} \\
\mathbf{L S})\end{array}$} & & & & & & & & & & & \\
\hline & & & $\mathbf{S}_{2}$ & $\mathbf{S}_{3}$ & & & $\mathbf{S}_{2}$ & $\mathbf{S}_{\mathbf{3}}$ & & & $\mathbf{S}_{2}$ & $\mathbf{S}_{\mathbf{3}}$ & \\
\hline & & & (35 LS) & $\begin{array}{l}(40 \\
\mathrm{LS})\end{array}$ & & & (35 LS) & $\begin{array}{l}(40 \\
\mathrm{LS})\end{array}$ & & & $\begin{array}{l}(35 \\
\text { LS })\end{array}$ & $\begin{array}{l}(40 \\
\text { LS) }\end{array}$ & \\
\hline $\mathbf{G}_{1}$ & NAA 10ppm & 72.78 & 78.67 & 90.01 & 80.49 & 78.36 & 85.06 & 90.44 & 84.62 & 75.57 & 81.87 & 90.23 & 82.55 \\
\hline $\mathbf{G}_{2}$ & NAA 20ppm & 76.00 & 72.25 & 90.92 & 79.72 & 71.04 & 80.37 & 88.36 & 79.92 & 73.52 & 76.31 & 89.64 & 79.82 \\
\hline $\mathbf{G}_{3}$ & Ethrel 10ppm & 82.47 & 82.68 & 93.68 & 86.28 & 72.01 & 91.37 & 90.77 & 84.72 & 77.24 & 87.02 & 92.23 & 85.50 \\
\hline $\mathbf{G}_{4}$ & Ethrel 30ppm & 85.73 & 91.03 & 95.26 & 90.67 & 78.38 & 80.06 & 93.37 & 83.94 & 82.06 & 85.54 & 94.32 & 87.31 \\
\hline $\mathbf{G}_{5}$ & Ethrel 50ppm & 76.36 & 91.09 & 94.00 & 87.15 & 71.71 & 73.02 & 91.01 & 78.58 & 74.03 & 82.05 & 92.51 & 82.86 \\
\hline $\mathbf{G}_{6}$ & NAA 10ppm + Ethrel 10ppm & 72.36 & 93.67 & 92.11 & 86.04 & 74.38 & 87.42 & 89.37 & 83.72 & 73.37 & 90.54 & 90.74 & 84.88 \\
\hline $\mathbf{G}_{7}$ & NAA 10ppm + Ethrel 30ppm & 79.92 & 81.16 & 92.05 & 84.38 & 72.35 & 79.06 & 88.36 & 79.92 & 76.14 & 80.11 & 90.21 & 82.15 \\
\hline $\mathbf{G}_{8}$ & NAA 10ppm + Ethrel 50ppm & 81.70 & 82.04 & 86.28 & 83.34 & 73.40 & 74.73 & 85.36 & 77.83 & 77.55 & 78.39 & 85.82 & 80.58 \\
\hline $\mathbf{G}_{9}$ & NAA 20ppm + Ethrel 10ppm & 85.70 & 82.21 & 86.00 & 84.64 & 77.07 & 79.39 & 88.03 & 81.50 & 81.39 & 80.80 & 87.02 & 83.07 \\
\hline $\mathbf{G}_{10}$ & NAA 20ppm + Ethrel 30ppm & 78.20 & 75.76 & 83.97 & 79.31 & 79.40 & 78.00 & 84.38 & 80.59 & 78.80 & 76.88 & 84.17 & 79.95 \\
\hline $\mathbf{G}_{11}$ & NAA 20ppm + Ethrel 50ppm & 79.39 & 78.82 & 83.90 & 80.70 & 79.38 & 81.00 & 84.36 & 81.58 & 79.39 & 79.91 & 84.13 & 81.14 \\
\hline $\mathbf{G}_{12}$ & Control (water spray) & 47.36 & 55.12 & 42.67 & 48.38 & 48.72 & 57.00 & 41.73 & 49.15 & 48.04 & 56.06 & 42.20 & 48.77 \\
\hline & Mean & 76.50 & 80.37 & 85.90 & & 73.02 & 78.87 & 84.63 & & 74.76 & 79.62 & 85.27 & \\
\hline & & $\begin{array}{l}\text { SEm } \\
\pm\end{array}$ & CD at $5 \%$ & $\mathbf{C V}$ & & $\begin{array}{l}\text { SEm } \\
\pm\end{array}$ & CD at $5 \%$ & CV & & $\begin{array}{l}\text { SEm } \\
\pm\end{array}$ & $\begin{array}{c}\text { CD at } \\
5 \%\end{array}$ & CV & \\
\hline & $\mathbf{G}$ & 2.39 & 6.75 & & & 2.30 & 6.48 & & & 1.81 & 5.11 & & \\
\hline & $\mathbf{S}$ & 1.20 & 3.38 & 2. & & 1.15 & 3.24 & & & 0.91 & 2.55 & & \\
\hline & GX S & 4.15 & 11.70 & & & 3.98 & 11.22 & & & 3.14 & 8.85 & & \\
\hline
\end{tabular}

30 LS - 30 leaves stage

$35 \mathrm{LS}-35$ leaves stage

40 LS - 40 leaves stage 
Table.2 Flowering (Days) of pineapple as influenced by various treatments

\begin{tabular}{|c|c|c|c|c|c|c|c|c|c|c|c|c|c|}
\hline \multirow{4}{*}{\multicolumn{2}{|c|}{ Growth regulators }} & \multirow{4}{*}{$\begin{array}{c}\mathbf{S}_{1} \\
(\mathbf{3 0} \\
\mathbf{L S})\end{array}$} & \multirow{2}{*}{\multicolumn{2}{|c|}{$\begin{array}{c}\text { 2017- } 2019 \\
\text { Stage of spray (S) }\end{array}$}} & \multirow{4}{*}{$\begin{array}{l}\text { Mea } \\
\text { n }\end{array}$} & \multirow{4}{*}{$\begin{array}{c}\mathbf{S}_{1} \\
(\mathbf{3 0} \\
\mathbf{L S})\end{array}$} & \multirow{2}{*}{\multicolumn{2}{|c|}{$\begin{array}{c}2018-2020 \\
\text { Stage of spray }(\mathrm{S})\end{array}$}} & \multirow{4}{*}{ Mean } & \multirow{4}{*}{$\begin{array}{c}\mathbf{S}_{1} \\
(\mathbf{3 0} \\
\mathbf{L S})\end{array}$} & \multirow{2}{*}{\multicolumn{2}{|c|}{$\begin{array}{c}\text { Pooled } \\
\text { Stage of spray (S) }\end{array}$}} & \multirow{4}{*}{ Mean } \\
\hline & & & & & & & & & & & & & \\
\hline & & & $\mathbf{S}_{2}$ & $\mathbf{S}_{\mathbf{3}}$ & & & $\mathbf{S}_{2}$ & $\mathbf{S}_{\mathbf{3}}$ & & & $\mathbf{S}_{2}$ & $\mathbf{S}_{\mathbf{3}}$ & \\
\hline & & & (35 LS) & $\begin{array}{l}(40 \\
\text { LS })\end{array}$ & & & (35 LS) & $\begin{array}{l}(40 \\
\text { LS })\end{array}$ & & & (35 LS) & $\begin{array}{l}(40 \\
\text { LS })\end{array}$ & \\
\hline $\mathbf{G}_{1}$ & NAA 10ppm & 40.67 & 36.33 & 32.33 & 36.44 & 40.33 & 35.00 & 32.67 & 36.00 & 40.50 & 35.67 & 32.50 & 36.22 \\
\hline $\mathbf{G}_{2}$ & NAA 20ppm & 40.00 & 34.67 & 32.33 & 35.67 & 39.00 & 35.00 & 32.67 & 35.56 & 39.50 & 34.83 & 32.50 & 35.61 \\
\hline $\mathbf{G}_{3}$ & Ethrel 10ppm & 39.67 & 33.67 & 32.33 & 35.22 & 37.00 & 35.33 & 32.33 & 34.89 & 38.33 & 34.50 & 32.33 & 35.06 \\
\hline $\mathbf{G}_{4}$ & Ethrel 30ppm & 35.00 & 35.33 & 32.00 & 34.11 & 41.33 & 32.00 & 31.00 & 34.78 & 38.17 & 33.67 & 31.50 & 34.44 \\
\hline $\mathbf{G}_{5}$ & Ethrel 50ppm & 38.00 & 36.33 & 31.00 & 35.11 & 36.00 & 37.33 & 32.33 & 35.22 & 37.00 & 36.83 & 31.67 & 35.17 \\
\hline $\mathbf{G}_{6}$ & NAA 10ppm + Ethrel 10ppm & 39.67 & 33.67 & 33.00 & 35.44 & 41.67 & 37.67 & 33.00 & 37.44 & 40.67 & 35.67 & 33.00 & 36.44 \\
\hline $\mathbf{G}_{7}$ & NAA 10ppm + Ethrel 30ppm & 38.33 & 34.67 & 33.67 & 35.56 & 40.00 & 37.33 & 34.00 & 37.11 & 39.17 & 36.00 & 33.83 & 36.33 \\
\hline $\mathbf{G}_{8}$ & NAA 10ppm + Ethrel 50ppm & 36.00 & 38.67 & 35.00 & 36.56 & 42.33 & 35.00 & 35.00 & 37.44 & 39.17 & 36.83 & 35.00 & 37.00 \\
\hline $\mathbf{G}_{9}$ & NAA 20ppm + Ethrel 10ppm & 43.00 & 34.00 & 37.67 & 38.22 & 46.33 & 33.33 & 35.67 & 38.44 & 44.67 & 33.67 & 36.67 & 38.33 \\
\hline $\mathbf{G}_{10}$ & NAA 20ppm + Ethrel 30ppm & 43.33 & 37.33 & 37.67 & 39.44 & 42.67 & 40.67 & 37.33 & 40.22 & 43.00 & 39.00 & 37.50 & 39.83 \\
\hline $\mathbf{G}_{11}$ & NAA 20ppm + Ethrel 50ppm & 40.00 & 38.33 & 38.33 & 38.89 & 39.67 & 37.33 & 37.33 & 38.11 & 39.83 & 37.83 & 37.83 & 38.50 \\
\hline $\mathbf{G}_{12}$ & Control (water spray) & 52.67 & 77.67 & 58.33 & 62.89 & 58.00 & 76.67 & 67.33 & 67.33 & 55.33 & 77.17 & 62.83 & 65.11 \\
\hline & Mean & 40.53 & 39.22 & 36.14 & & 42.03 & 39.39 & 36.72 & & 41.28 & 39.31 & 36.43 & \\
\hline & & $\begin{array}{c}\text { SEm } \\
\pm\end{array}$ & CD at $5 \%$ & $\mathbf{C V}$ & $\%)$ & $\begin{array}{c}\text { SEm } \\
\pm\end{array}$ & CD at $5 \%$ & CV & & $\begin{array}{c}\text { SEm } \\
\pm\end{array}$ & CD at $5 \%$ & CV & \\
\hline & $\mathbf{G}$ & 1.95 & 5.50 & & & 1.75 & 4.94 & & & 1.53 & 4.32 & & \\
\hline & $\mathbf{S}$ & 0.98 & 2.75 & & & 0.88 & 2.47 & & & 0.77 & 2.16 & & 93 \\
\hline & $\mathbf{G} \times \mathbf{S}$ & 3.38 & 9.53 & & & 3.03 & 8.56 & & & 2.65 & 7.48 & & \\
\hline
\end{tabular}

$30 \mathrm{LS}-30$ leaves stage

$35 \mathrm{LS}-35$ leaves stage

$40 \mathrm{LS}-40$ leaves stage 
Different stages had significant and greater influence on days to flower in pineapple. Early flowering (36.43 days) was noticed in plants of 40 leaves stage. Delayed flowering (41.28 days) was recorded in 30 Leaves stage plants $\left(\mathrm{S}_{1}\right)$.

The interaction effects between growth regulators and stage of spray had a significant influence with respect to days to flowering. The interaction of Ethrel $30 \mathrm{ppm}$ and 40 leaves stage took minimum (31.50) number of days for initiation of flowering followed by Ethrel 50 ppm (31.67 days), Ethrel 10 ppm(32.33 days), NAA 10 ppm (32.50 days), NAA 10 ppm (32.50 days). While maximum number of days (77.17) were required in plants grown under water treatment in 30 leaves stage plants.

The data pertaining to floral characters (Table $1 \& 2$ ) showed appreciable effect of growth regulators. Maximum flowering percentage $(87.31 \%)$ was recorded under treatment Ethrel $30 \mathrm{ppm}$. Unsaturated hydrocarbons like ethylene and acetylene are capable of forcing pineapple plant to flower. Ethrel induced a sharp peak of flower initiation at all the concentrations tried within 50 days of the treatment. Next to Ethrel NAA was effective, but the results during the two trials showed a wider variation with regard to the effectiveness of different concentrations. Ethrel may alter the endogenous auxin level to a threshold concentration which cause flowering in this plant. Ethrel is highly potential in inducing flower formation in pineapple plants and it can induce a plant to flower in any season if it attains the minimum age required for initiation of flowering. The highest flowering percentage of flowering with Ethrel application was also reported by Borang et al., (2017), Liu et al., (2011) in pineapple, Kumar et al., (2017), Prasad et al., (2018) in litchi, Gawankar et al., (2010) and Ghadage et al., (2016) in cashew.
Van Overbeek (1951) postulated that ethylene may bring about metabolic changes in the vegetative apex making the tissue more responsive to the auxins it contains, there by bringing about floral induction.

Bartholomew (1977) observed that the flower bud development was evident on 7 days after application of ethephon. In the axils of the bracts the flower primordia was first observed on 11 days after treatment. After 25 days of treatment flower initiation ceased but the average time required for the maximum of about $95 \%$ flower/inflorescence was 34 days.

The higher concentration of plant regulators viz., NAA and Ethrel delayed the period of first flower initiation because the higher concentration might be having toxic effect on yield parameters. This might be due to the $\mathrm{C}$ : $\mathrm{N}$ ratio, which helps in balanced management of vegetative and reproductive phases and thereby promote early flowering. The production and supply of photosynthesis at critical stage induces the more flowering as well as fruits set. These results are in accordance with the findings of Singh et al., (2007) in aonla.

It is evident from the results obtained that, stage of spray had significantly influenced on various floral characters like flowering percentage and days to flowering. In the present investigation, it was observed that 40 leaves stage significantly affected the floral characters of pineapple fruit. The analysis of pooled data showed that 40 leaves stage had maximum flowering percentage $(85.27 \%)$ and minimum days to flowering (36.43days). If the plants are too small they cannot be induced to flower successfully even if treated with ethephon (Van de Poel et al., 2009).

Interaction effect of growth regulators and stages of spray significantly influenced flowering percent and Days to flower 
induction. Maximum flowering percent (94.32\%) and Days to flower induction (31.50 Days) were obtained in combined treatment of Ethrel 30ppm and 40 leaves stage. Kuan et al., (2005), Vences et al., (2018) and Das Biswas et al.(1983) reported similar results in pineapple.

Application of Ethrel (40 \%) between 390 and 420 days after planting when the plants had 43.7 to 46.2 leaves improved flower induction. The forcing at later stages (390-420 days) showed higher number of slip formation /plant and the days required for flower formation was delayed (Mitra et al., 1993). The correct and timely application of ethephon gives better yield, plant uniformity, along with synchronous flowering, spreading of the crop, predetermined harvesting time, improved management and economical cultivation (Teisson, 1979).

In conclusion the effect of growth regulators had a pronounced effect on flowering characteristics of pineapple. The maximum value for flowering percentage $(87.31 \%)$ and minimum value for days to flower induction (31.50 days) were recorded for the treatment $\mathrm{G}_{4}$ (Ethrel 30ppm).

The effect of stage of spray was found to be significant on floral characters of pineapple. The maximum flowering percentage (85.27 $\%$ ) and minimum days taken for flowering (36.43days) were found for the treatment 40 leaves stage.

\section{References}

Bartholomew, D.P.1977. Inflorescence development of pineapple (Ananas comosus (L.) Merr.) induced to flower with ethephon. Botanical Gazette. 138:312-320.

BorangSiyang. 2015. Forced flowering of pineapple (Ananas comosus cv. Kew) in rersponse to cold stress, ethephon, calcium carbide and activated charcoal. College of Horticulture and Forestry, Central Agricultural University, Pasighat.

Cunha, G.A.P., Costa, J.T.A. and Reinhardt, D.H. 2003. Natural flowering on pineapple: inhibition by growth regulators. Fruits. 58(1):27-37.

Das Biswas, S., Dhua, R.S., Mitra, S.K. and Bose, T.K. 1983. Physiological studies on flowering of pineapple in response to chemicals and environment. Acta Horticulturae. 137: 231-242.

FAO. 2018. FAOSTAT. Food and Agriculture Organization of the United Nations, Rome, Italy.

Gawankar, M. S., Sawale, R. D., Pawar, S. N. and Chavan, S. A. 2010.Effect of Ethrel on flowering, sex-expression and yield in cashew. Journal of Horticultural Sciences.5(1): 68-70.

Ghadage, V. R., Ahlawat, T. R., Chawla, S. L., Shah, N. I. and Ghadage, N. 2016. Effect of plant growth regulators on flowering behavior of cashew cv. Vengurla-4 grown in the hilly tracts of South Gujarat. Journal of Applied and Natural Science. 8 (1): 23 - 27.

Kuan, C.S., Yu, C.W., Lin, M.L. and Hsu, H.T. 2005. Foliar application of aviglycine reduces natural flowering in pineapple. Hortscience. 40:123-126.

Kumar, K., Pinder, R., Jitender., Dabas, S.T.K.S., Yadav, B. and Rana,S.2017. Effect of growth regulators and micronutrients on fruit cracking and fruit yield in pomegranate. Indian Journal of Agricultural Research. 51 (3): 272-276.

Liu Sheng-hui, L., Xiao-ping, Z. and Guangming, S. 2011. Changes in endogenous hormone concentrations during inflorescence induction and development in pineapple (Ananas comosus cv. Smooth Cayenne) by ethephon. Academic Journals. 11: 124. 
Mitra, S.K., Biswas, B. and Hussain, M. 1993. Effect of plant age on flower induction in pineapple cv. Kew. Indian Journal of Horticulture. 50(1): 14-17.

Prasad, M., Sahay, S., Patel, V.B., Kumar, R., Raj, A., Sengupta, S. and Kundu, M.2018. Effect of foliar application of PGR and different potassium forms on sex expression, fruit setting, yield and fruit quality in litchi 'Mandraji'. ActaHorticulturae. 1211:1-6.

Singh, C., Sharma, H.K. and Sarkar, B.C. 2007. Optimization of process conditions during osmotic dehydration of fresh pineapple. Journal of Food Science and Technology. 45. 312-316.

Teisson, C. 1979. Internal browning of pineapples: Research on means of control. Fruits. 34: 399-411.

Van Overbeek, J. 1951. Use of growth substances in tropical agriculture. In Plant growth substances. University of Wisconsin Press. Madison. 224-225.

Vences, C. V.2018. Plant Age and Rate of Flower Inducer Affects Flower Initiation of 'MD2' Pineapple (Ananas comosus L.). International Journal of Research \& Review. 5(4):27.

Van de Poel, B., Johan, C. and Maurice, D.P. 2009. Determination of pineapple (Ananas comosus, MD2 hybrid cultivar), plant maturity, the efficiency of flowering induction agents and the use of activated carbon. Scientia Horticulturae. 120: 58-63.

\section{How to cite this article:}

Usha Kumari, K. K. Jha, S. Sengupta, S. Misra, A. K. Tiwary and Chakraborty, M. 2020. Effect of NAA and Ethrel on Flowering Characteristics of Pineapple (Ananas comosus L. Merr.) Var. Queen. Int.J.Curr.Microbiol.App.Sci. 9(11): 2818-2824. doi: https://doi.org/10.20546/ijcmas.2020.911.341 